\title{
Flt-3 and Its Ligand Are Expressed in Neural Crest-Derived Tumors and Promote Survival and Proliferation of Their Cell Lines
}

\author{
Fabio Timeus, Emanuela Ricotti, Nicoletta Crescenzio, Emanuela Garelli, \\ Alessandra Doria, Monica Spinelli, Ugo Ramenghi, and Giuseppe Basso \\ Department of Pediatrics (FT, ER, NC, EG, AD, UR, GB), University of Torino, Turin, and Laboratory of \\ Hemato-oncology (MS), Department of Pediatrics, University of Padova, Padua, Italy
}

SUMMARY: Flt-3 ligand (FL) is a cytokine that promotes the survival, proliferation, and differentiation of hematopoietic progenitors in synergy with other growth factors, such as stem cell factor. Previously we have demonstrated that stem cell factor and its receptor c-kit are expressed in neural crest-derived tumor cells and that a c-kit block induces their apoptosis. Here we have evaluated the expression of flt-3 and its ligand in 12 neuroectodermal tumor cell lines from neuroblastoma (NB), neuroepithelioma (NE), Ewing sarcoma (ES), and peripheral neuroectodermal tumor (PNET) and in 38 biopsies: 19 from NB and 19 from ES and PNET. RT-PCR demonstrated the expression of flt-3 and FL in all lines. Coexpression was observed in $42 \%$ of NB and in $74 \%$ of ES and PNET biopsies. Flow cytometry confirmed the presence of membrane and cytoplasmic flt-3 and membrane FL in all lines, whereas soluble FL protein was not measurable in their supernatants. Microphysiometric demonstration of acidification of the medium provided evidence of the specific response of cell lines to FL stimulation. Specific flt-3 phosphorylation after FL treatment was also demonstrated by Western blotting analysis. In cells growing in RPMI plus $1 \%$ fetal calf serum, FL revealed a significant proliferating activity, more evident in NB and NE lines (mean increase of viable cells, $73 \pm$ $26 \%$ after 1 day). Treatment with flt-3 antisense oligonucleotides significantly inhibited cell growth. FL also displayed an antiapoptotic activity: after a 12 -hour culture in the presence of $0.1 \%$ fetal calf serum, FL caused a $50 \%$ reduction of apoptotic cells. These results provide further evidence that neuroectodermal and hematopoietic cells share common regulatory pathways, and could be of interest in the clinical management of neuroectodermal tumors. (Lab Invest 2001, 81:1025-1037).

$F$ It-3 is a transmembrane glycoprotein. Like the $F$ stem cell factor (SCF) receptor (c-kit) and those for M-CSF (c-fms/FMS) and PDGF (PDGFRA and PDGFRB), it belongs to the tyrosine kinase receptor class III (Lyman et al, 1993; Rosnet and Birnbaum, 1993; Rosnet et al, 1991; Shibuya et al, 1990). Flt-3 is expressed on human hematopoietic progenitors, immature thymocytes, monocytes, acute myelogenous leukemia (AML) and B cell precursors acute lymphoblastic leukemia (ALL), mouse fetal liver, and various adult mouse tissues, such as brain and cerebellum (Birg et al 1992; Drexler et al 1999; Rosnet et al, 1993). Its ligand, flt-3 ligand (FL), is a cytokine that promotes the proliferation, survival, and differentiation of hematopoietic progenitors (Broxmeyer et al, 1995; Hannum et al, 1994; Lyman et al, 1994; Rasko et al, 1995; Vanu et al, 1999; Zeigler et al, 1994) in synergy with other growth factors, namely SCF, IL-3, IL-6, IL-11, IL-12, and GM-CSF (Drouet et al, 1999; Jacobsen et al, 1995). In association with G-CSF, FL mobilizes stem

Received April 5, 2001.

This study was supported by grants from Ministero dell'Università e della Ricerca Scientifica e Tecnologica (MURST), Associazione Italiana per la Ricerca sul Cancro (A.I.R.C.), and Fondazione Città della Speranza. Address reprint requests to: Dr. Fabio Timeus, Pediatric Hematology Unit, University of Torino, Piazza Polonia 94, 10126 Torino, Italy. E-mail: timeus@pediatria.unito.it and progenitor cells to peripheral blood (Molineux et al, 1997; Papayannopoulou et al, 1997). It plays an important role in lymphopoiesis (in synergy with IL-7) and in the production of dendritic cells (Hunte et al, 1996; Ohm et al, 1999; Ray et al, 1996). All of these biological functions make FL potentially useful in various clinical settings (Lyman, 1998).

SCF and c-kit (Bernstein et al, 1991; Yarden et al, 1987; Zsebo et al, 1990) are involved in development of the peripheral nervous system and are expressed in neural crest-derived tumor cells (Cohen et al, 1994). c-kit block induces neuroectodermal tumor cell apoptosis (Ricotti et al, 1998, 1999; Timeus et al, 1997). Neural and hematopoietic cells are closely correlated and "hematopoietic" growth factors such as FL are active in the generation of neural cells from bone marrow mesenchymal stem cells (Reyes and Verfaillie, 1999).

SCF and FL synergize in the regulation of hemopoiesis (Lyman and Jacobsen, 1998). The role of FL/flt-3 alone and its possible cooperation with SCF/c-kit in the biology of neuroectodermal tumors are investigated in this study.

\section{Results}

RT-PCR analysis demonstrated the expression of flt-3 and FL RNA in all 12 lines (Fig. 1). Flt-3 RNA was 

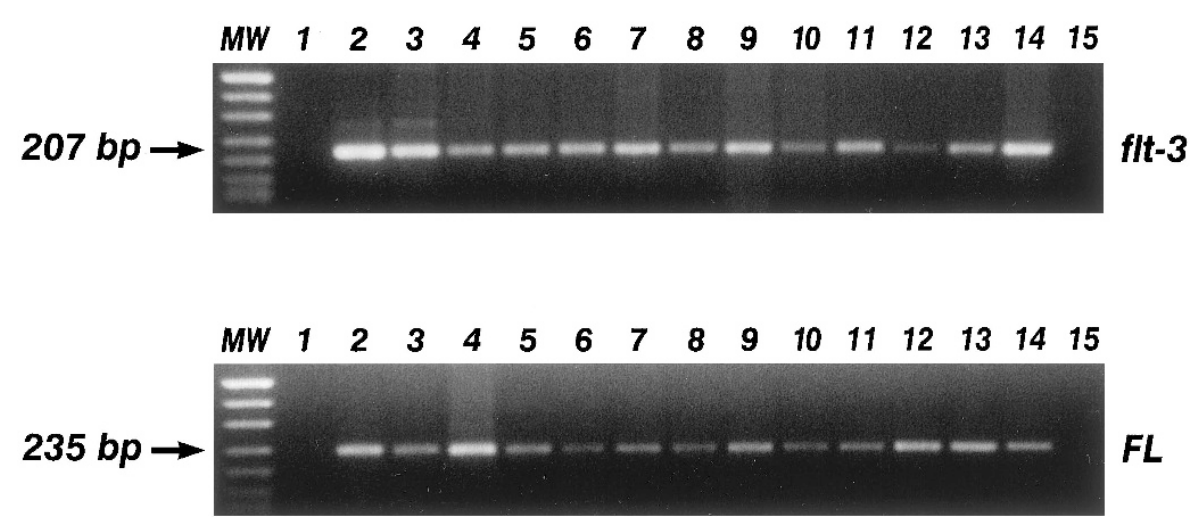

Figure 1.

RT-PCR analysis of flt-3 and Flt-3 ligand (FL) expression in 12 neuroblastoma (NB), neuroepithelioma (NE), Ewing sarcoma (ES), and peripheral neuroectodermal tumor (PNET) cell lines. The specific flt-3 207 bp and the FL 235 bp fragments are visible in all lines. MW: molecular weight marker. Lane 1: negative control (K-562 for flt-3 and M07-E for FL). Lane 2: positive control (HL60 for flt-3 and 5637 for FL). Lanes 3 to 14: CHP-100, AF8, IMR-5, SK-N-SH, SJ-N-KP, SK-N-BE, 6647, TC32, TC106, PDN13, PDE02, PDN12. Lane 15: no DNA.

expressed in 14 of 19 neuroblastoma (NB) and 17 of 19 Ewing sarcoma (ES) and peripheral neuroectodermal tumor (PNET) biopsies; FL was expressed in 9 of 19 NB and in 14 of 19 ES and PNET biopsies. Flt-3/FL coexpression was observed in $42 \%$ of NB biopsies and in $74 \%$ of ES and PNET biopsies (Table 1, Fig. 2).

Flow cytometry showed the presence of membrane and cytoplasmic flt-3 and membrane FL in all lines (Fig. 3), whereas soluble FL protein (evaluated by ELISA) was not measurable. Cell lines responded to $\mathrm{FL}$ stimulation by acidifying the medium in a concentration-dependent manner, as demonstrated by the cytosensor (Fig. 4); the peak rate was reached after about 2 minutes at $2,500 \mathrm{ng} / 10^{6}$ cells FL concentration.

Inhibition of the receptor-response by pretreating the FL preparation with a suitable concentration of specific FL-neutralizing antibody provided the evidence for cytokine/receptor-specific activity (Fig. 5). Specific flt-3 phosphorylation after FL treatment was demonstrated by using Western blotting analysis on flt-3 immunoprecipitates (Fig. 6).

When the lines were cultured in medium supplemented with $1 \%$ fetal calf serum (FCS), the presence of FL significantly $(p<0.005)$ increased the number of viable cells (evaluated by trypan blue exclusion) after 1 to 3 days of culture (Table 2, Fig. 7). This activity was more evident in NB and NE lines (mean increase vs controls, $73 \pm 26 \%$ after one day and $50 \pm 23 \%$ after 3 days). The association FL + SCF showed an additive effect. Treatment with flt-3 and c-kit antisense oligonucleotides specifically inhibited cell growth from the sixth day. After a 9-day culture in the presence of flt-3 antisense, cellular flt-3 expression decreased (data not shown) and there was a $45 \%$ specific reduction of viable cells (Table 3 , Fig. 8).

FL showed a significant antiapoptotic activity in the experiments at $0.1 \%$ FCS: after a 12-hour culture, FL caused a $50 \%$ reduction of apoptotic cells, as demonstrated by flow cytometry for annexin $\mathrm{V}$ (Table 4, Fig. 9). SCF showed a similar behavior. FL + SCF had the same antiapoptotic effect as the single cytokines.

\section{Discussion}

FL and SCF are cytokines that play a crucial role in regulation of the early phases of hemopoiesis. They protect stem cells from apoptosis and, in cooperation with other growth factors, promote the proliferation of hemopoietic progenitors. Their activities on these progenitors mostly overlap, but are often synergic. Many data point to the existence of a relatively early progenitor coexpressing c-kit and flt-3. Hematopoietic and nervous systems have a similar differentiation pathway from a stem cell to various final elements. Recent data suggest the existence of a common stem cell that can alternatively differentiate to the hematopoietic or nervous direction: donor-derived hematopoietic cells develop in sublethally irradiated mice transplanted with neural stem cells (Bjornson et al, 1999) and marrow cells differentiate into microglia and macroglia (Eglitis and Mezey, 1997). We have previously demonstrated that the system SCF/c-kit is expressed in primitive neuroectodermal tumors and exerts an in

Table 1. RT PCR Analysis of FL and flt-3 Expression in NB, NE, ES and PNET Tumor Cell Lines and Biopsies

\begin{tabular}{lcccc}
\hline & $\mathrm{FL}+\mathrm{flt}-3+$ & $\mathrm{FL}+\mathrm{flt}-3-$ & $\mathrm{FL}-\mathrm{flt}-3+$ & $\mathrm{FL}-\mathrm{flt}-3-$ \\
\hline NB and NE lines (6) & 6 & 0 & 0 & 0 \\
ES and PNET lines (6) & 6 & 0 & 0 & 0 \\
NB biopsies (19) & 8 & 1 & 6 & 4 \\
ES and PNET biopsies (19) & 14 & 0 & 3 & 2 \\
\hline
\end{tabular}

FL, FIt-3 ligand; NB, neuroblastoma; NE, neuroepithelioma; ES, Ewing sarcoma; PNET, peripheral neuroectodermal tumor. 
A
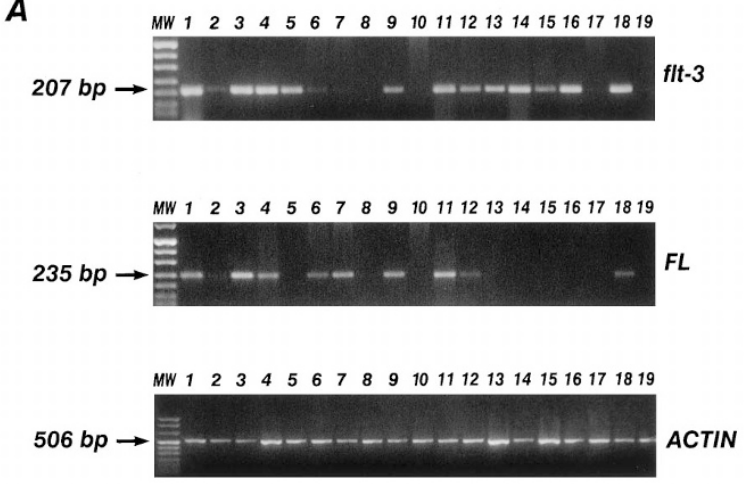

B
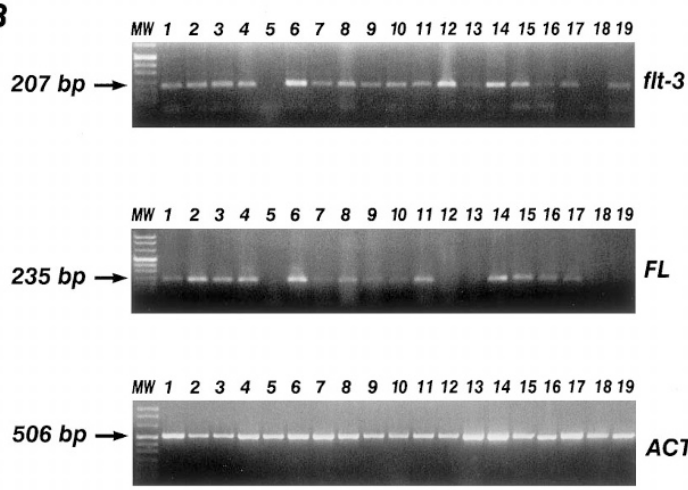

ACTIN

\section{Figure 2.}

RT-PCR analysis of flt-3 and FL expression in 19 biopsies from NB and NE (A) and 19 biopsies from ES and PNET (B) cell lines. The specific flt-3 207 bp fragment is visible in 14 biopsies in A and 17 biopsies in B. The specific FL 235 bp fragment is visible in 9 biopsies in A and 14 biopsies in B. Amplification of $\beta$-actin mRNA was used as a control and yielded a 506 bp product.

vitro proliferative and antiapoptotic activity on their cell lines.

We now show that neural crest-derived tumors express both flt-3 and FL m-RNA. Their lines also express membrane and cytoplasmic flt-3 protein and FL protein in a membrane-bound form. This is probably the first demonstration that flt-3 and its ligand are expressed in neural crest-derived tumor cell lines. PCR performed on biopsies substantiates our results by giving them biological significance and ruling out aberrations of cell lines.

The expression of FL/flt-3 and SCF/c-kit in neural crest-derived tumor cells and their proliferative and antiapoptotic activity provide further evidence that hematopoietic and neural progenitors share common regulatory systems (Quesenberry et al, 1999; SieberBlum, 1998). Whereas in neuroectodermal tumor cell lines, c-kit expression decreases according to differentiation, as in the hemopoietic progenitors, and is lowest in the more differentiated neuroblastoma lines (Ricotti et al, 1998; Timeus et al, 1997), flt-3 expression is similar in ES, PNET, and neuroblastoma lines and is thus unrelated to differentiation of neural progenitors.

Proliferation and apoptosis experiments demonstrated a functional role of $\mathrm{FL} / \mathrm{flt}-3$ in the regulation of these tumor lines. In cultures with a suboptimal FCS concentration (1\%), addition of FL significantly increased the number of viable cells from the first day. The increase was higher after 1 than after 3 days, probably because of the increasing number of cells per well. In these experimental conditions, FL showed a direct proliferating activity, whereas its antiapoptotic effect was negligible (not shown). Confirmation of the role of flt-3 in the proliferation of neuroectodermal tumor cells was provided by the demonstration that flt-3 antisense oligonucleotides significantly reduced the number of viable cells from the sixth culture day. In the experiments with very low FCS concentration (0.1\%), FL also showed a significant antiapoptotic activity, like SCF, with a $50 \%$ reduction of apoptotic cells after a 12-hour culture.

As previously discussed, SCF and FL often show a synergic activity on the hematopoietic progenitors. In the neuroectodermal tumor cell lines, their association displayed an additive rather than a synergic effect in the proliferation assays, whereas its antiapoptotic effect was the same as that of the single cytokines. This may reflect the existence of a threshold of maximal antiapoptotic activity. Similar results were observed when cultures were carried out in the presence of antisense oligonucleotides and in cytosensor experiments in which flt-3 + SCF caused the same acidification as that of the single cytokines (not shown).

The in vitro proliferative and antiapoptotic activity of FL/flt-3 was negligible in standard culture conditions (10\% FCS) in which other factors presumably hold cell viability and proliferation at an optimal level.

FL protein was only present in a membrane-bound form in the cell lines and its soluble form was undetectable in their supernatants; this could be attributed to a rapid self-utilization of FL from cells or to a very low FL level in the supernatants, not detected by our method. FL/flt-3 coexpression in most lines and tumors points to an autocrine loop mediated by cell-tocell interactions. This mechanism could be more substantial in ES and PNET than in NB and NE (FL/flt-3 coexpression in $74 \%$ and $42 \%$ of biopsies, respectively) and certainly plays a favorable role in tumor proliferation. Only further experiments on normal human tissues can clarify whether it is a causal factor in tumor transformation.

All biopsies were obtained from stage III and IV tumors. The prognostic value of FL/flt-3 expression is under investigation.

In conclusion, our data demonstrate that FL and flt-3 are expressed in neuroectodermal tumors and in neuroblastoma where they exert a biological activity by promoting the survival and proliferation of tumor cells. The clinical usefulness of these data needs further investigation. The fact that hemopoietic growth factors stimulate neuroectodermal tumor cells provides further evidence of a common ancestral precursor for neuroectodermal and hematopoietic cells. FL mobilizes hematopoietic progenitors and promotes dendritic cell production and is therefore potentially suitable for cancer therapy. Our data suggest that its 
CL
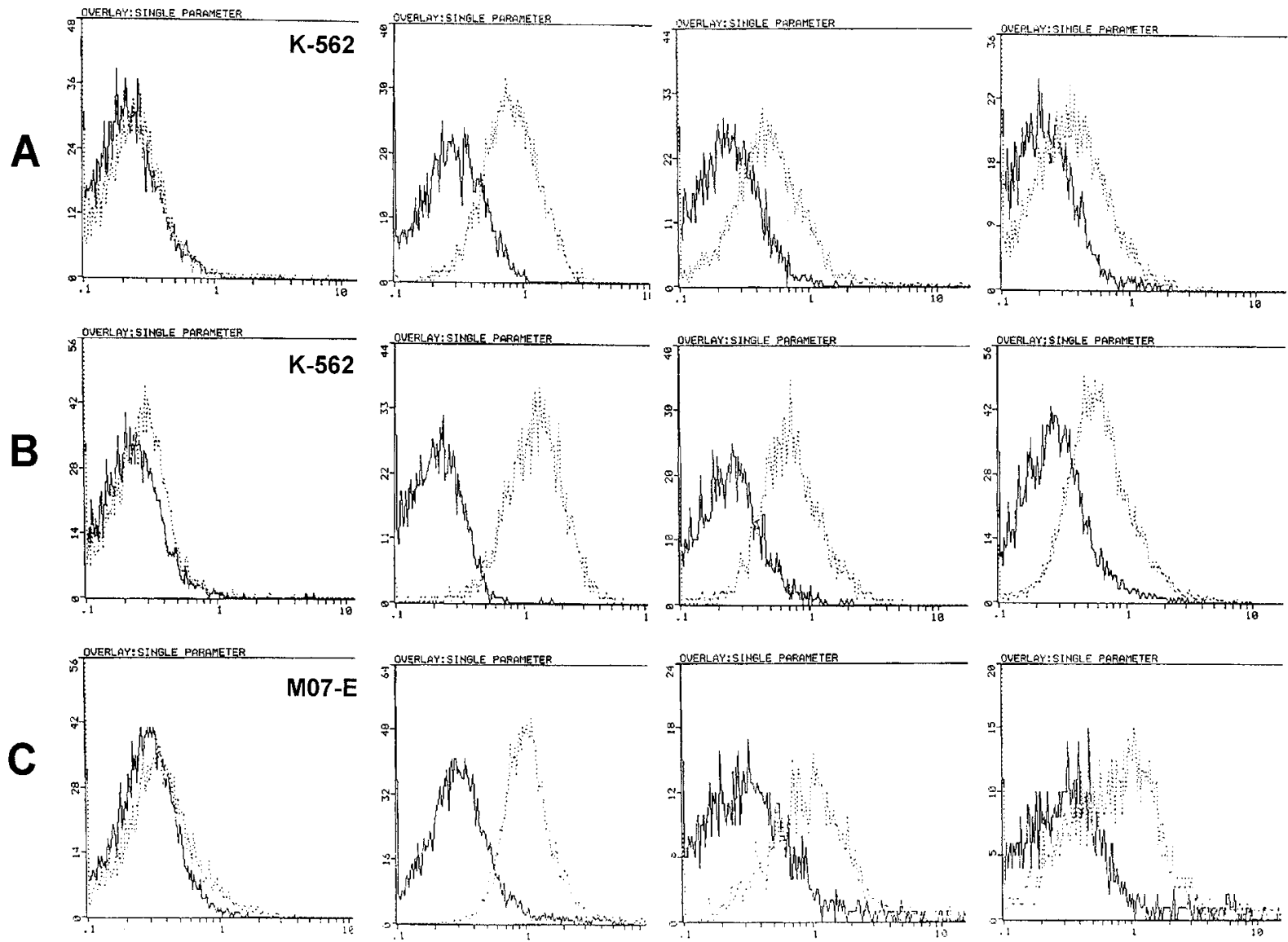

Figure 3.

Flow cytometry evaluation of flt-3 and FL expression in SJ-N-KP (NB), PDN12 (PNET), PDE02 (ES) cell lines. For surface flt-3 detection, the anti-flt-3 PE-conjugated BV10A4H2 MoAb was used. For the detection of intracellular flt-3, cells were first treated with the Fix and Perm Cell permeabilization kit. Surface FL expression was investigated by indirect flow cytometry using the anti-FL 40406.111 MoAb as primary antibody and the goat antimouse F(ab)2 FITC-conjugated MoAb as secondary antibody. The K-562 and M07-E lines were used as negative controls (CL) for flt-3 and FL, respectively. A, Surface flt-3. B, Flt-3 expression after cell wall permeabilization. C, Surface FL.

clinical use in neural crest-derived tumors ought to be cautiously evaluated.

\section{Materials and Methods}

\section{Cell Lines}

Twelve tumor cell lines of neuroectodermal origin: six NB and NE lines (IMR-5, SK-N-SH, SK-N-BE, AF8, SJ-N-KP, CHP-100), three ES lines (6647, TC106, PDE02), and three PNET lines (PDN12, PDN13, TC32) (Biedler et al, 1973, 1978; Pagani et al, 1998; Rocchi et al, 1987; Schlesinger et al, 1976; Thiele et al, 1987) were cultured in RPMI 1640 (GIBCO, Grand Island, New York) plus $10 \%, 1 \%$, or $0.1 \%$ FCS (Irvine, Santa Ana, California). The TC32 cell line was used only for molecular studies. As controls, the M-07E line (Avanzi et al, 1990) was maintained in Iscove's modified Dulbecco's medium (GIBCO) supplemented with 5\% FCS and rhGM-CSF (Sandoz, Basel, Switzerland) 150 $\mathrm{U} / \mathrm{ml}$, and K-562, 5637, and HL60 lines were cultured in RPMI 1640 plus $10 \%$ FCS.
Supernatants for ELISA were obtained by culture at $5 \times 10^{4}$ cells $/ \mathrm{ml}$. The conditioned medium was removed after 72 hours, centrifuged, filtered, and assayed.

\section{Biopsies}

Nineteen biopsies from stage III and IV NB (kindly provided by Dr. G. P. Tonini, Genova) and 19 biopsies from ES and PNET (all with the chimeric fusion gene product EWS/FLI1, kindly provided by Dr. E. Frascella, Padova) were analyzed. All diagnoses were confirmed by a reference team of Italian Pediatric Hematology and Oncology Association (AIEOP) pathologists.

\section{RT-PCR Analysis}

Total RNA was extracted by the guanidine salts and phenol-chloroform method (Ultraspec RNA; Biotecx 


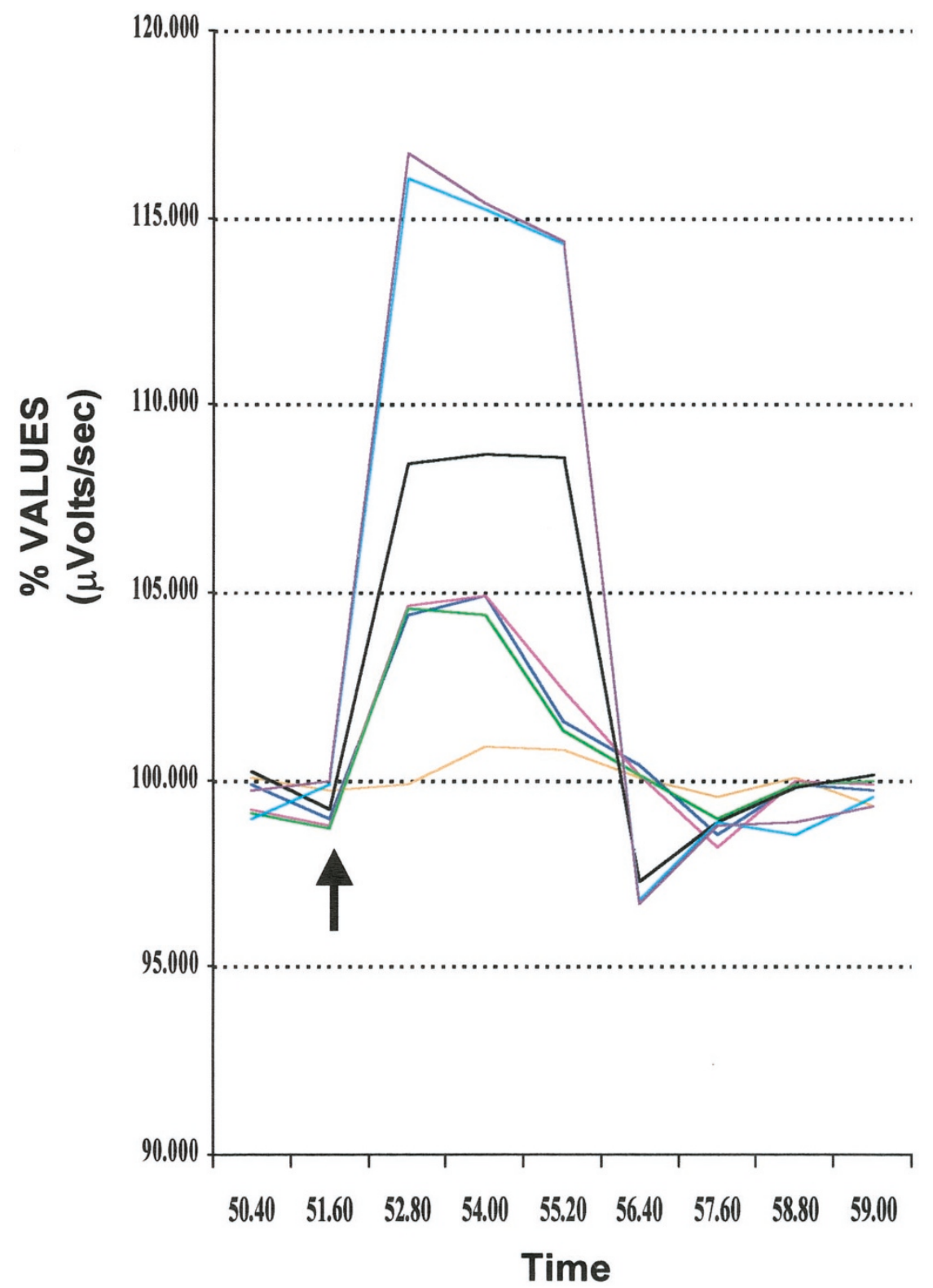

Figure 4.

Cytosoft rate window demonstrating the dose-response curve of SJ-N-KP cells exposed to FL. Concentrations (in ng/ $10^{6}$ cells): 0 (orange), 1.25 (dark blue), 12.5

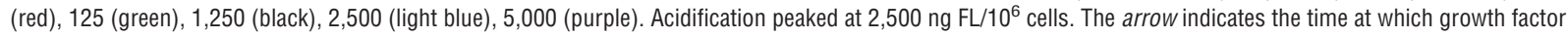
was added. Time: minutes, $1 \mu \mathrm{V} / \mathrm{sec}=1 \mathrm{millipH} /$ minute

Laboratories, Houston, Texas). cDNA was prepared from $2 \mu \mathrm{g}$ of total RNA, using poly-T as primer and MMLV reverse transcriptase (GeneAmp RNA PCR Kit; Perkin Elmer, Foster City, California). PCR was performed in a Perkin Elmer GeneAmp PCR System 9700 , using one-fourth of the reverse transcription product and $25 \mathrm{pmol}$ of each oligonucleotide as primers. After one denaturation step at $96^{\circ} \mathrm{C}$ for 3 minutes, 35 cycles of amplification were performed: denaturation at $94^{\circ} \mathrm{C}$ for 1 minute, annealing at $65^{\circ} \mathrm{C}$ or $69^{\circ} \mathrm{C}$ (for flt-3 and FL, respectively) for 1 minute, synthesis at $72^{\circ} \mathrm{C}$ for 1 minute, and extension at $72^{\circ} \mathrm{C}$ for 5 minutes. Oligonucleotides for flt-3 expression analysis were: sense primer 5'-CAAGTGCTGTGCATACAATTCCC-3' (positions 1536-1558 on the sequence), antisense primer 5'-ACCTGTACCATCTGTAGCTGG-3' (positions 1722-1742) (Rosnet et al, 1993); oligonucleotides for FL were: sense primer 5'TGTCAGCCCGACTCCTCAACC-3' (positions 555-575) and antisense primer 5'-AGTGCTCCACAAGCAGCAGGT-3' (positions 769-789) (Lisovsky et al, 1996). To check cDNA quality, beta-actin was amplified using sense primer 5'-CCACTGGCATCGTGATGGACT-3' and antisense primer 5'-TCCTTCTGCATCCTGTCGGC-3' (Ponte et al, 1984).

One-tenth of the amplified products was run on $2 \%$ agarose gels in $1 \times$ Tris borate buffer and visualized with ethidium bromide. The M07-E and K-562 lines were used as negative controls for FL and flt-3, respectively. 5637 and HL60 were the positive controls. 


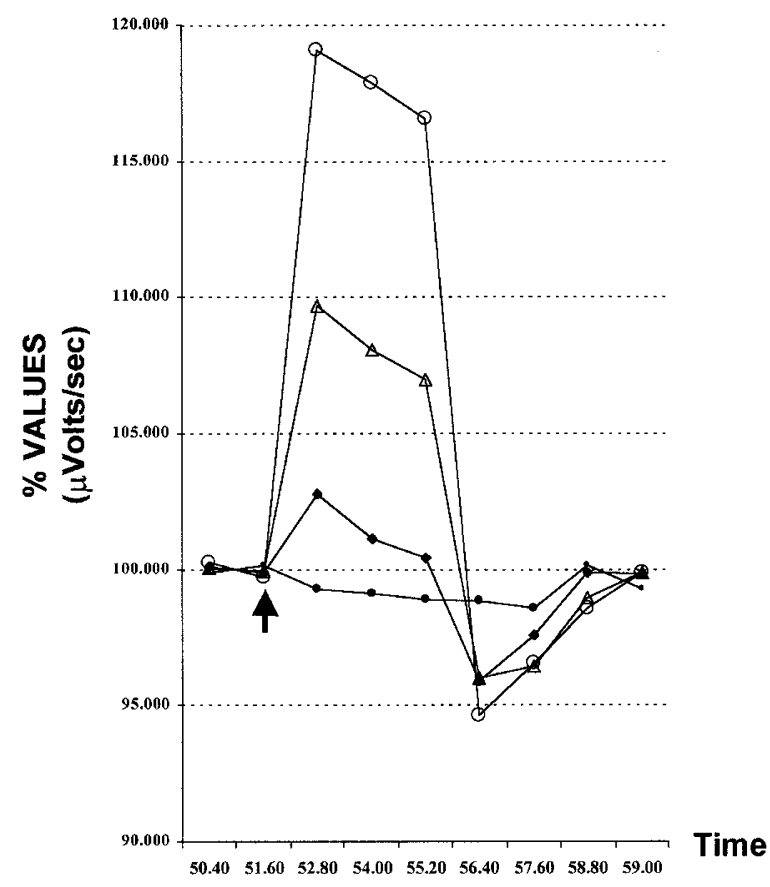

Figure 5.

Cytosoft rate window demonstrating the real-time response of SJ-N-KP cells to a 6-minute exposure to $2,500 \mathrm{ng} F \mathrm{FL}(0) / 10^{6}$ cells, 2,500 ng anti-FL neutralizing antibody $(\diamond) / 10^{6}$ cells, FL plus anti-FL $(\Delta)$. Medium alone, $(\bullet)$. The arrow indicates the time at which growth factor and neutralizing antibody were added. The peak reached after 2 minutes is followed by a rapid return to the baseline despite the continuing exposure of cells to the growth factor. Time: minutes, $1 \mu \mathrm{V} / \mathrm{sec}=1 \mathrm{millipH} /$ minute.

\section{Enzyme Immunoassay for Soluble FL Protein}

Soluble FL protein was determined according to the manufacturer's instructions by ELISA (Quantikine; R \& D Systems, Minneapolis, Minnesota) in conditioned medium of NB, NE, ES, and PNET lines cultured for 72 hours. Briefly, 96-well microtiter plates coated with a murine monoclonal antibody against FL were used. One hundred microliters of assay diluent were added to each well, then FL standards and samples $(50 \mu \mathrm{l})$ were added and incubated for 2 hours at room temperature. After washing, an enzyme-linked polyclonal antibody specific for FL $(200 \mu \mathrm{l})$ was added for 1.5 hours. Two hundred microliters of peroxidase substrate were added and incubated for 20 minutes at room temperature. Absorbance was read at $450 \mathrm{~nm}$ with a Microplate Reader (Bio-Rad Laboratories, Milan, Italy). The minimum detectable concentration of FL was 7 pg/ml. The control was RPMI 1640 medium.

\section{Flow Cytometry Evaluation of Flt-3 and FL Expression}

Cell lines were tested for the presence of surface flt-3 and FL and cytoplasmic flt-3. Scraped cells $\left(2 \times 10^{5}\right)$ were incubated with $5 \mu \mathrm{l}$ anti-flt-3 PE-conjugated BV10A4H2 (Caltag, San Francisco, California) for 20 minutes at $4^{\circ} \mathrm{C}$, then washed with PBS plus $1 \% \mathrm{w} / \mathrm{v}$ bovine serum albumin before analysis with a flow cytometer EPICS XL (Coulter, Miami Lake, Florida) equipped with an argon laser. Isotype PE conjugate was used as negative control. To detect cytoplasmic

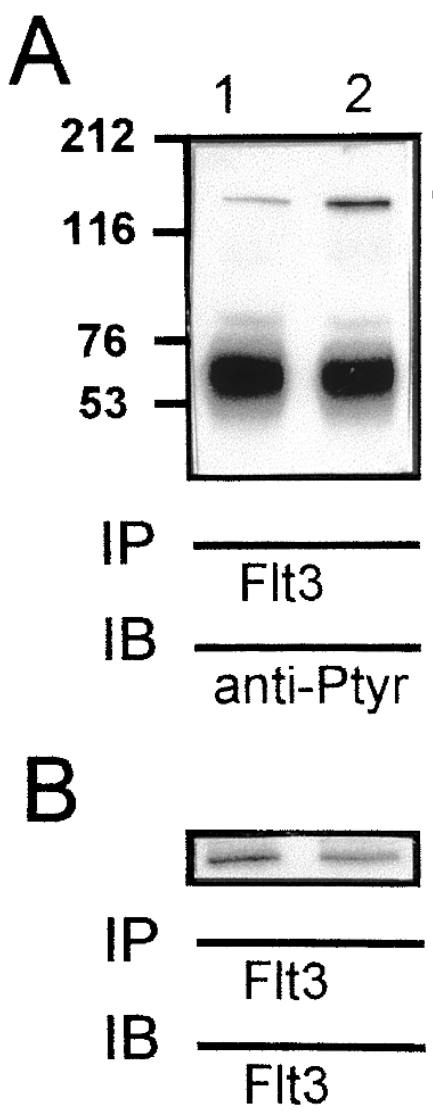

Figure 6.

A, FL-induced tyrosine phosphorylation of flt3. SJNKP cells were incubated for 10 minutes with $2.5 \mu \mathrm{g} \mathrm{FL} / 10^{6}$ cells, lysed, and immunoprecipitated with Flt3 antiserum. Proteins were resolved by $7.5 \%$ SDS-PAGE, transferred to nitrocellulose, and immunoblotted with antiphosphotyrosine antibody. The molecular mass of protein standards is indicated in $\mathrm{kDa}$. 1, Untreated cells; 2, FL-treated cells. B, Flt3 immunoblot. The immunoblot from A was stripped and reprobed with an anti-flt3 polyclonal antibody.

flt-3, cells were incubated according to the manufacturer's instructions in $100 \mu \mathrm{l}$ fixing solution (Fix and Perm Cell permeabilization kit; Caltag) for 15 minutes at room temperature, washed in PBS, resuspended in permeabilizing solution in the presence of $5 \mu \mathrm{l} \mathrm{PE}$ conjugated BV10A4H2, incubated for 15 minutes at room temperature, and then washed and analyzed as described. Cord blood CD34+ cells and K-562 cells were used as the positive and negative control, respectively. Surface FL expression was investigated by indirect flow cytometry using anti-FL 40406.111 MoAb (R \& D Systems, Milan, Italy) as primary antibody and goat antimouse F(ab)2 FITC-conjugated MoAb (Technogenetics, Milan, Italy) as secondary antibody. The M07-E line was used as negative control.

\section{Cytosensor Experiments}

An innovative instrument, the microphysiometer "Cytosensor" (Molecular Devices, Sunnyvale, California), which measures the ligand/receptor reaction from the output of acid from cells (McConnell et al 1992; Salon and Owicki, 1994), was used to study the response to FL stimulation of SJ-N-KP and PDN12 cell lines. Cells 
Table 2. Percentage Increase of Viable Cells over Basal Values in Cultures ${ }^{a}$

\begin{tabular}{lrrrrrrrrrr}
\hline & $\mathrm{FL}$ & $\mathrm{SCF}$ & $\mathrm{FL}+\mathrm{SCF}$ & $\mathrm{FL}$ & \multicolumn{2}{c}{$\mathrm{SCF}$} & $\mathrm{FL}+\mathrm{SCF}$ & \multicolumn{2}{c}{$\mathrm{FL}$} & \multicolumn{2}{c}{$\mathrm{SCF}$} & \multicolumn{2}{c}{$\mathrm{FL}+\mathrm{SCF}$} \\
& $24 \mathrm{~h}$ & $24 \mathrm{~h}$ & $24 \mathrm{~h}$ & $48 \mathrm{~h}$ & $48 \mathrm{~h}$ & $48 \mathrm{~h}$ & $72 \mathrm{~h}$ & $72 \mathrm{~h}$ & $72 \mathrm{~h}$ \\
\hline AF-8 & 67 & 76 & 251 & 34 & 29 & 57 & 48 & 34 & 77 \\
SJ-N-KP & 85 & 113 & 236 & 148 & 145 & 235 & 86 & 65 & 122 \\
IMR-5 & 110 & 85 & 165 & 52 & 67 & 128 & 34 & 36 & 60 \\
CHP-100 & 83 & 59 & 175 & 68 & 75 & 130 & 69 & 80 & 122 \\
SK-N-BE & 52 & 58 & 135 & 36 & 42 & 75 & 32 & 15 & 58 \\
SK-N-SH & 38 & 26 & 95 & 52 & 73 & 133 & 29 & 50 & 94 \\
TC106 & 29 & 13 & 75 & 40 & 56 & 63 & 19 & 27 & 47 \\
PDN13 & 58 & 50 & 113 & 39 & 63 & 108 & 37 & 16 & 55 \\
6647 & 65 & 65 & 155 & 26 & 57 & 103 & 21 & 10 & 60 \\
PDE02 & 50 & 38 & 96 & 39 & 53 & 110 & 42 & 52 & 92 \\
PDN12 & 57 & 74 & 148 & 33 & 30 & 66 & 54 & 38 & 84 \\
m \pm SD & $63 \pm 23$ & $60 \pm 28$ & $149 \pm 56$ & $51 \pm 34$ & $63 \pm 31$ & $119 \pm 50$ & $43 \pm 20$ & $38 \pm 22$ & $79 \pm 26$ \\
\hline
\end{tabular}

SCF, stem cell factor.

${ }^{a}$ Cultures carried out in the presence of FCS $1 \%$ with the addition of $50 \mathrm{ng} / \mathrm{mL}$ FL, $50 \mathrm{ng} / \mathrm{mL} \mathrm{SCF}, 50 \mathrm{ng} / \mathrm{mL}$ FL $+50 \mathrm{ng} / \mathrm{mL}$ SCF for 24,48 , and $72 \mathrm{hours}$.

All increases were significant, $p<0.005$.

in RPMI 1640 were seeded into cytosensor capsule cups 18 hours before the experiment. The capsules were then transferred into a silicon-containing sensor chamber. The instrument measures the rate of output of acid from cells (acidification rate); the fluid flow is periodically halted to allow a build-up of acid metabolites in the chamber. Determination of the baseline acidification rate from eight replicate chambers after normalizing data was followed by introduction of the effector agent, and its effect on the acidification rate was monitored. The FL working concentration was calculated from a dose-response curve in which the cells were incubated for 6 minutes with $0,1.25,12.5$, 125, 1,250, 2,500, and 5,000 ng FL/10 ${ }^{6}$ cells. Acidification peaked with FL $2500 \mathrm{ng} / 10^{6}$ cells. This concentration was used to demonstrate ligand-receptor specificity by adding an anti-FL neutralizing antibody ( $R$ \& D Systems) at $25,000 \mathrm{ng} / 10^{6}$ cells. Synergy between FL and SCF was evaluated in other experiments that compared SCF $\left(500 \mathrm{ng} / 10^{6}\right.$ cells) with $\mathrm{FL}+$ SCF.

\section{Proliferation Assays}

NB, NE, ES, and PNET cell lines were cultured $(2 \times$ $10^{4} / \mathrm{ml}$ ) in RPMI 1640 plus $1 \%$ FCS with or without 50 $\mathrm{ng} / \mathrm{ml}$ recombinant human $\mathrm{FL}, 50 \mathrm{ng} / \mathrm{ml}$ recombinant human SCF, $50 \mathrm{ng} / \mathrm{ml} \mathrm{FL}+50 \mathrm{ng} / \mathrm{ml} \mathrm{SCF} \mathrm{(R} \mathrm{and} \mathrm{D}$ Systems), alone and associated with $0.5 \mu \mathrm{g} / \mathrm{ml}$ anti-FL (40406.111 MoAb, R and D Systems) and $20 \mu \mathrm{g} / \mathrm{ml}$ anti-SCF (goat IgG polyclonal Ab; R \& D Systems) neutralizing antibodies. Cultures were also performed in the presence of $50 \mathrm{ng} / \mathrm{ml} \mathrm{IL-2,} \mathrm{as} \mathrm{negative} \mathrm{control.}$ Cytokines and antibodies were added every day. After 24,48 , and 72 hours, cells were trypsinized and viable cells were counted by trypan blue exclusion in a Neubauer chamber. All assays were performed in triplicate. The increase in the number of cells was determined by comparison with day zero.

In further experiments, cells cultured in RPMI 1640 $+10 \%$ FCS were exposed to phosphorothioate anti- sense oligonucleotide for flt-3, c-kit, flt-3+c-kit (4 $\mu \mathrm{M}$; TIB MOLBIOL, Genova, Italy; flt-3 antisense sequence: 5'- CXTXgX CXgXCX CXAXAX CXgXCX CXCXgX CXAXT; c-kit antisense sequence: 5'- gXCXCX gXCXgX AXgXCX gXCXCX TXCXTX CXAXT; X= phosphorothioate modification), according to previously described methods (Ricotti et al, 1998), for 3, 6, and 9 days. The uptake of FITC-conjugated antisense oligonucleotides had been previously determined. An example is shown in Figure 10. Antisense oligonucleotides were added to cultures every day. Cultures with sense and randomized-sequence phosphorothioate oligonucleotides were also performed. The K562 line was used as negative control. After 3, 6, and 9 days, cells were trypsinized and viable cells were counted by trypan blue exclusion. The increase in the number of viable cells was calculated by comparison with day zero. The specific inhibition of cell growth was determined as the difference between cell growth inhibition caused by antisense and sense oligonucleotides.

\section{Evaluation of Apoptosis}

Apoptosis of NB, NE, ES, and PNET cells cultured $(2 \times$ $10^{4} / \mathrm{ml}$ ) in RPMI 1640 plus $0.1 \%$ FCS with or without $50 \mathrm{ng} / \mathrm{ml} \mathrm{FL}, 50 \mathrm{ng} / \mathrm{ml} \mathrm{SCF}, 50 \mathrm{ng} / \mathrm{ml} \mathrm{FL}+50 \mathrm{ng} / \mathrm{ml}$ SCF for 72 hours was evaluated by flow cytometry, using annexin V-FITC conjugates (Apoptosis Detection Kits; R and D Systems), according to the manufacturer's instructions. Briefly, cells were first washed with PBS containing calcium and then incubated for 15 minutes at room temperature with $0.025 \mu \mathrm{g}$ annexin V-FITC and $0.5 \mu \mathrm{g}$ propidium iodide before analysis with a EPICS XL2 flow cytometer. All of the experiments were performed in triplicate. Cytospin preparations were stained with May GrunwaldGiemsa for morphologic evaluation of apoptotic cells.

\section{Immunoprecipitation Studies}

The ability of FL to induce protein tyrosine phosphorylation in the SJ-N-KP cell line was determined. Cells 

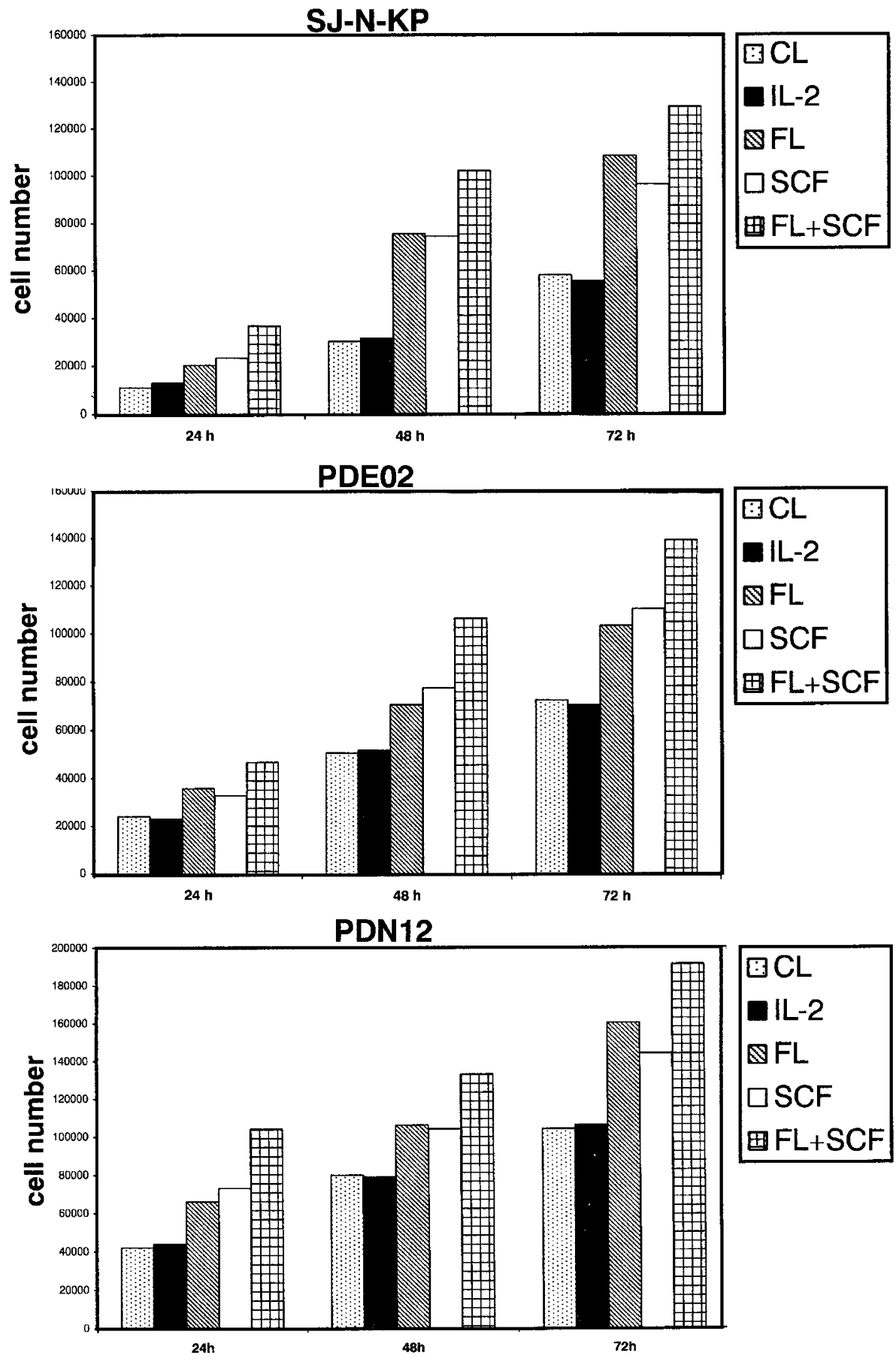

Figure 7.

Proliferation assays in SJ-N-KP, PDE02, and PDN12 lines. Cells were cultured for 24, 48, and 72 hours in RPMI 1640 plus $1 \%$ FCS in the presence or absence of $50 \mathrm{ng} / \mathrm{ml} \mathrm{FL}, 50 \mathrm{ng} / \mathrm{ml} \mathrm{SCF}, 50 \mathrm{ng} / \mathrm{ml} \mathrm{FL}+50 \mathrm{ng} / \mathrm{ml} \mathrm{SCF}$, and $50 \mathrm{ng} / \mathrm{ml} \mathrm{IL-2}$ as negative control. After trypsinization, viable cells were counted by trypan blue exclusion in a Neubauer chamber. Y axis, cell number; CL, control.

were resuspended in RPMI medium supplemented with $0.1 \% \mathrm{FCS}$, incubated for 24 hours at $37^{\circ} \mathrm{C}$ in $5 \%$ $\mathrm{CO}_{2}$, then untreated and FL-treated cells (10 minutes with $50 \mathrm{ng} / 2 \times 10^{4}$ cells) were rapidly pelleted and resuspended in lysis buffer $(10 \mathrm{~mm}$ Tris- $\mathrm{HCl}, \mathrm{pH} 8.6$, $1.5 \mathrm{~mm} \mathrm{MgCl}_{2}, 0.14 \mathrm{M} \mathrm{NaCl}, 1 \% \mathrm{NP} 40,2 \mathrm{~mm}$ phenylmethylsulfonylfluoride, $2 \mu \mathrm{g} / \mathrm{ml}$ leupeptin, $2 \mu \mathrm{g} / \mathrm{ml}$ aprotinin, $1 \mathrm{mg} / \mathrm{ml}$ pepstatin A). Lysates were incubated for a minimum of 30 minutes on ice, frozen, thawed, and centrifuged at $13,000 \mathrm{rpm}$ at $4^{\circ} \mathrm{C}$ for 20 minutes. Immunoprecipitation of flt-3 was performed on the clarified supernatant with a rabbit polyclonal antihuman flt-3 (Santa Cruz Biotechnology, Santa Cruz, California) after 1 hour of rotation at $4^{\circ} \mathrm{C}$. Protein A-Agarose (Santa Cruz Biotechnology) was added and the rotation was prolonged for 16 hours at $4^{\circ} \mathrm{C}$. Immunoprecipitates were than washed twice with lysis buffer, once with lysis buffer without NP-40, and once 
Table 3. Proliferation Assays in Neuroectodermal Tumor Cell Lines ${ }^{a}$

\begin{tabular}{|c|c|c|c|c|c|c|c|}
\hline & $\mathrm{R}$ & flt-3 S & flt-3 A & c-kit S & c-kit A & $S+S$ & $A+A$ \\
\hline D3 NB\&NE & 84 & 86 & 68 & 86 & 70 & 93 & 69 \\
\hline D3 ES & 86 & 84 & 62 & 90 & 65 & 75 & 56 \\
\hline D3 PNET & 91 & 95 & 84 & 90 & 79 & 88 & 72 \\
\hline D3 K562 ${ }^{b}$ & 84 & 88 & 94 & 88 & 96 & 99 & 96 \\
\hline D6 NB\&NE & 88 & 81 & 61 & 79 & 66 & 81 & 57 \\
\hline D6 ES & 80 & 75 & 44 & 86 & 59 & 78 & 42 \\
\hline D6 PNET & 92 & 86 & 34 & 83 & 37 & 78 & 40 \\
\hline $\mathrm{D} 6 \mathrm{~K} 562^{b}$ & 90 & 98 & 94 & 98 & 100 & 93 & 100 \\
\hline D9 NB\&NE & 81 & 78 & 54 & 80 & 53 & 82 & 47 \\
\hline D9 ES & 90 & 87 & 24 & 83 & 28 & 72 & 16 \\
\hline D9 PNET & 85 & 88 & 39 & 89 & 36 & 80 & 39 \\
\hline D9 K562 ${ }^{b}$ & 89 & 87 & 95 & 92 & 92 & 89 & 92 \\
\hline
\end{tabular}

$\mathrm{R}$, randomized-sequence oligonucleotide; $\mathrm{S}$, sense oligonucleotide; $\mathrm{A}$, antisense oligonucleotide; $\mathrm{S}+\mathrm{S}$, flt-3 $+\mathrm{c}-\mathrm{kit}$ sense oligonucleotide; $\mathrm{A}+\mathrm{A}$, flt-3 $+\mathrm{c}-\mathrm{kit}$ antisense oligonucleotide.

${ }^{a}$ Tumor cell lines were cultured in RPMI $+10 \%$ FCS plus $4 \mu \mathrm{m}$ randomized-sequence phosphorothioate oligonucleotide, flt-3, and c-kit sense or antisense oligonucleotides. Cultures were evaluated after 3 days (D3), 6 days (D6) and 9 days (D9). Values express the percentage of increase of viable cells in comparison to basal values. NB\&NE, ES, PNET: mean of increase of viable cells respectively in NB and NE, ES, and PNET lines.

${ }^{b}$ The K562 line was used as negative control.
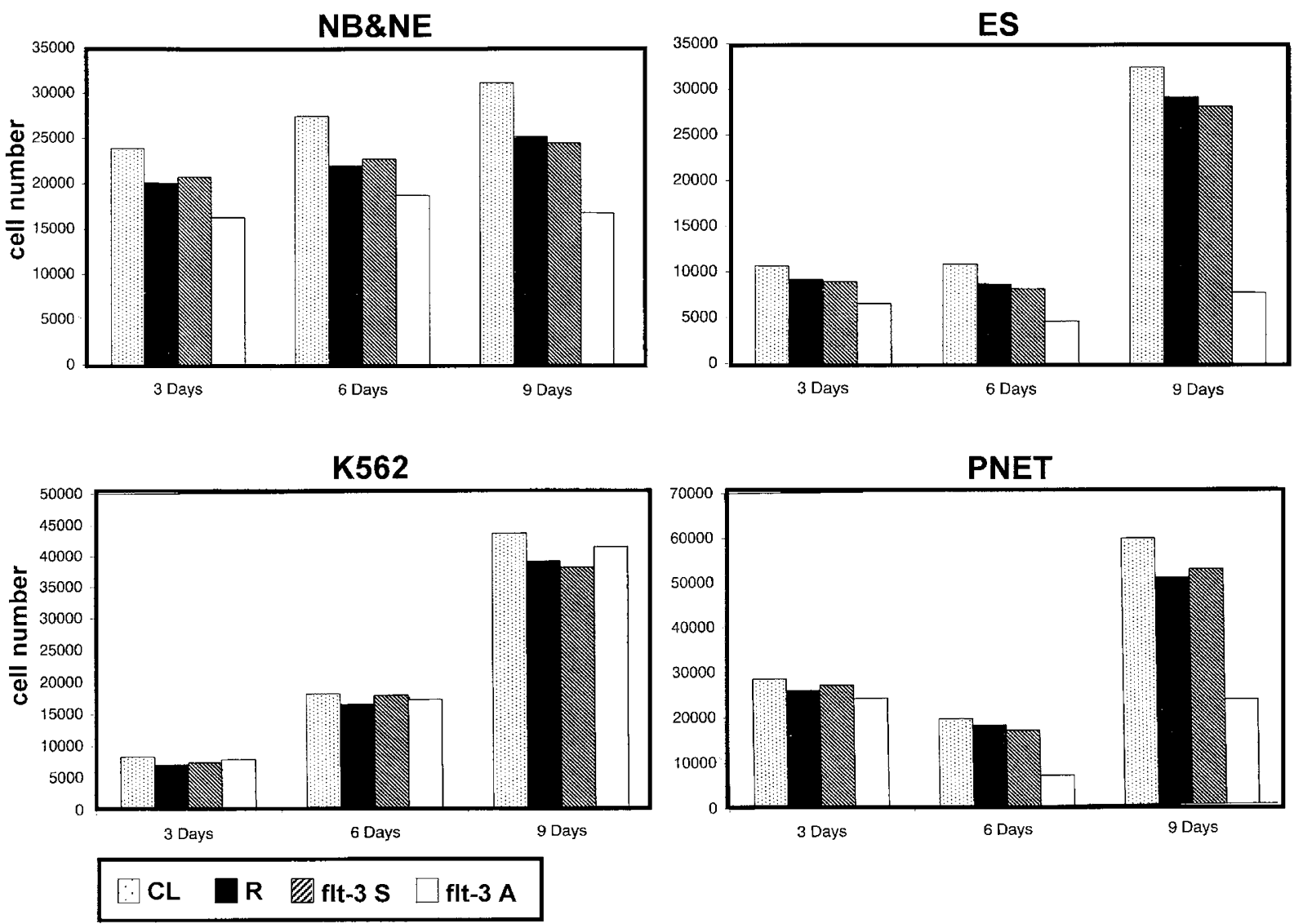

Figure 8.

Proliferation assays in NB+NE, ES, and PNET lines after 3-, 6-, and 9-day cultures in RPMI 1640 with 10\% FCS (CL, control) or RPMI 1640 with $10 \%$ FCS plus 4 $\mu \mathrm{M}$ phosphorothioate antisense oligonucleotide for flt-3 (flt-3 A), sense oligonucleotides for flt-3 (flt-3 S), and randomized-sequence phosphorothioate oligonucleotides (R). The oligonucleotides were added to cultures every day. After trypsinization, viable cells were counted by trypan blue exclusion in a Neubauer chamber. Data express the mean of the results of the experiments performed with five NB and NE lines, three ES lines, and three PNET lines. The K562 line was used as negative control. Y axis, cell number. 
Table 4. Percentage of Apoptotic Cells after 12-Hour Culture with Various Supplements

\begin{tabular}{lcccc}
\hline & $0.1 \% \mathrm{FCS}^{a}$ & $\mathrm{FL}^{b}$ & $\mathrm{SCF}^{c}$ & ${\mathrm{FL}+\mathrm{SCF}^{d}}^{c}$ \\
\hline SJ-N-KP & 43.9 & 19.4 & 14.1 & 17.3 \\
PDN12 & 78.8 & 43.6 & 53.8 & 47.3 \\
6647 & 28.0 & 15.9 & 7.4 & 5.6 \\
TC106 & 31.1 & 19.5 & 23.5 & 22.1 \\
SK-N-BE & 30.2 & 13.8 & 19.8 & 19.6 \\
CHP100 & 34.5 & 37.8 & 14.6 & 14.3 \\
IMR-5 & 61.7 & 26.8 & 36.2 & 30.5 \\
AF8 & 57.9 & 20.9 & 28.2 & 15.3 \\
PDN13 & 31.2 & 22.5 & 13.3 & 20.8 \\
SK-N-SH & 42.9 & 17.4 & 24.1 & 13.3 \\
PDE02 & 36.4 & $22.4 \pm 10.1^{\text {** }}$ & $22.9 \pm 12.9^{* *}$ & $22.5 \pm 12.4^{\text {** }}$ \\
m \pm SD & $43.3 \pm 16.2$ & & &
\end{tabular}

FCS, fetal calf serum.

a $0.1 \%$ FCS alone.

${ }^{b} 0.1 \%$ FCS plus $50 \mathrm{ng} / \mathrm{ml} \mathrm{FL}$.

${ }^{c} 50 \mathrm{ng} / \mathrm{ml} \mathrm{SCF}$.

${ }^{d} 50 \mathrm{ng} / \mathrm{ml} \mathrm{FL}+50 \mathrm{ng} / \mathrm{ml} \mathrm{SCF}$.

** Significantly different from control cultures, $p<0.005$.

\section{A}
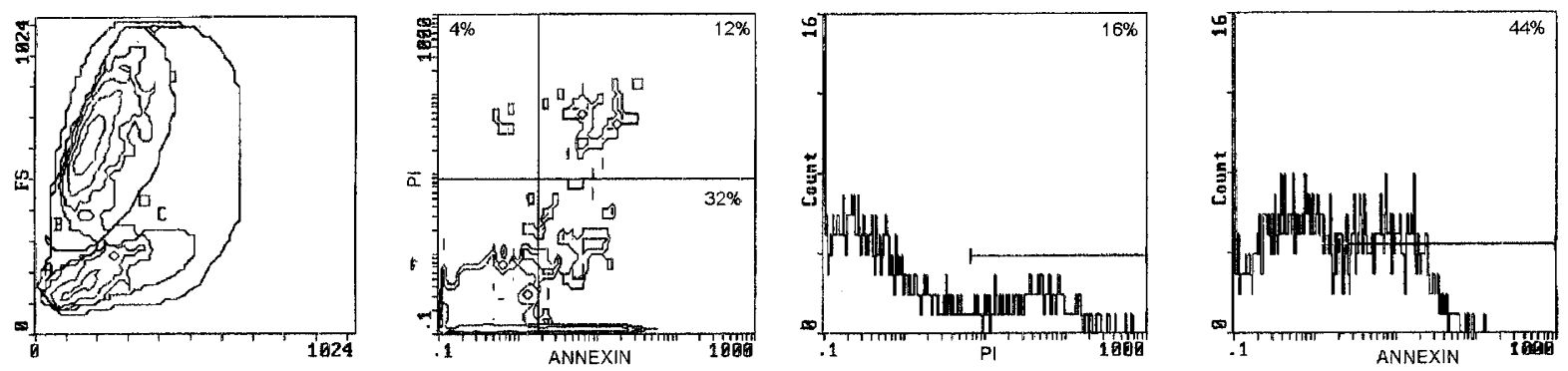

B
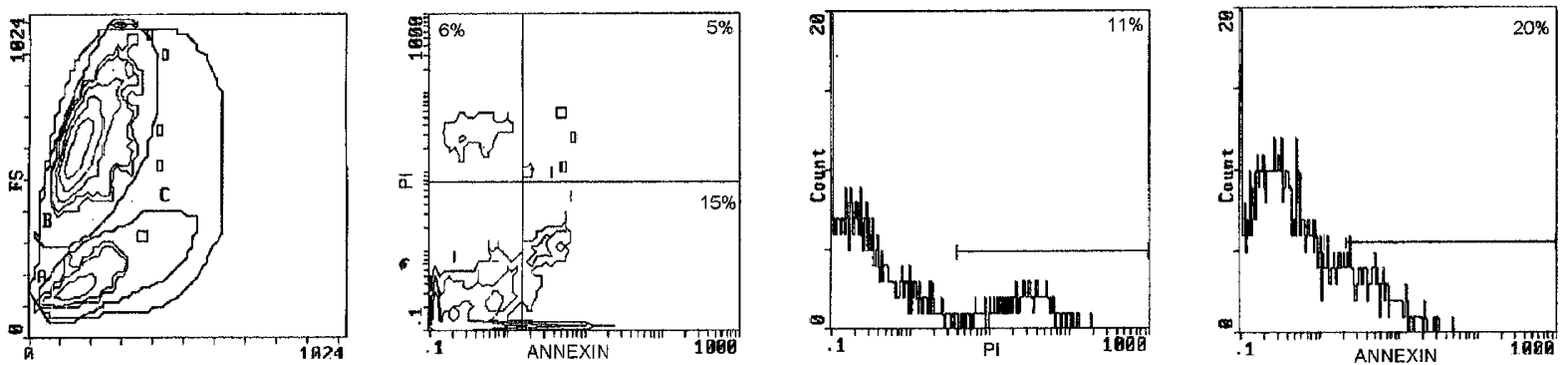

Figure 9.

Flow cytometry analysis demonstrating the antiapoptotic effect of $50 \mathrm{ng} / \mathrm{ml} \mathrm{FL}$ on SJ-N-KP line cultured for 12 hours in RPMl $1640+0.1 \%$ FCS (B) compared with control culture (RPMI $1640+0.1 \%$ FCS) (A). Gate B (upper gate): viable cells; gate C (lower gate): not viable cells. Dual-color analysis detects early apoptotic cells (annexin $\mathrm{V}+$ /propidium iodide-) and late apoptotic cells (annexin $\mathrm{V}+$ /propidium iodide+). Numbers in each panel show the percentage of apoptotic cells. Gate $\mathrm{A}$ $=\mathrm{B}+\mathrm{C}$.

with Tris- $\mathrm{HCl} 50 \mathrm{~mm}$, $\mathrm{pH}$ 6.5. Samples then underwent elution from protein $A$ with sodium dodecyl sulfate sample buffer. The resulting protein was subjected to 7.5\% SDS-PAGE with the PhastSystem (Amersham Pharmacia Biotech, Buckinghamshire, United Kingdom). Protein was transferred electrophoretically to nitrocellulose (Hybond ECL; Amersham) with Phast-
System. The filter was incubated with a $3 \%$ bovine albumin (Sigma, St. Louis, Missouri) blocking solution in TBS-Tween (20 mm Tris- $\mathrm{HCl}, \mathrm{pH}$ 7.6, $137 \mathrm{~mm} \mathrm{NaCl}$, $0.1 \%$ Tween 20 ) overnight at $4^{\circ} \mathrm{C}$. Antiphosphotyrosine antiserum 4G10 (Upstate Biotechnology, Lake Placid, New York) was added at the same solution and incubation was carried out for 2 hours at room tem- 


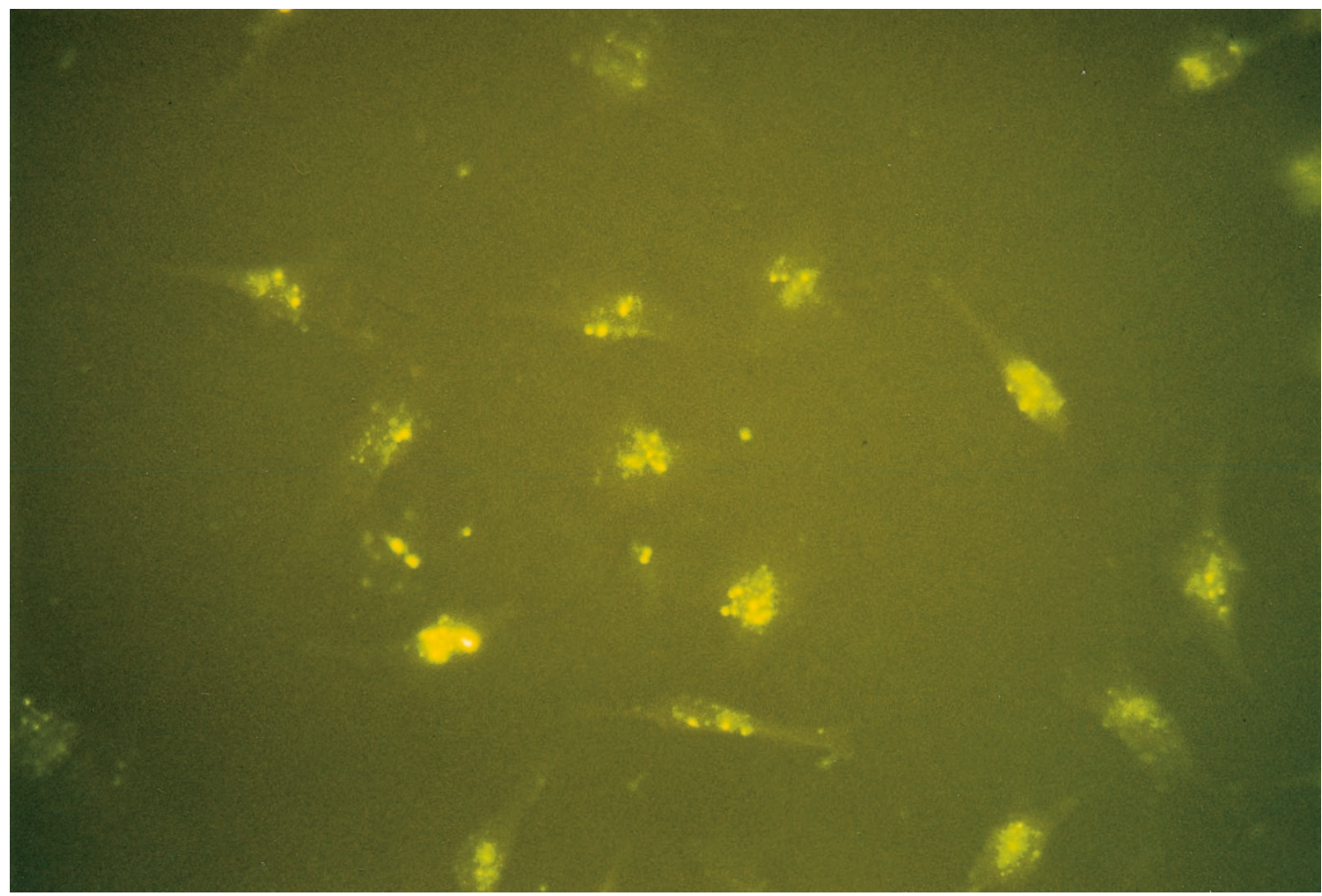

\section{Figure 10.}

Cytospin demonstrating the oligonucleotide uptake of the SJ-N-KP cell line cultured in RPMI $1640+10 \%$ FCS for 48 hours with $4 \mu \mathrm{m}$ FITC phosphorothioate antisense oligonucleotide for flt-3.

perature. The filter was then washed three times (10 minutes each) with TBS-Tween and reacted for 1 hour at room temperature with antimouse horseradish peroxidase-conjugated antibody (Amersham). The filter was again washed as above and visualized with the ECL Western blotting analysis system (Amersham). The nitrocellulose filter was stripped of antibody by $200 \mathrm{~mm}$ glycine, pH 2.2, SDS $0.1 \%$, Tween- $201 \%$, for 2 hours, then reprobed with anti flt-3 polyclonal antibody (Santa Cruz Biotechnology).

\section{Statistical Analysis}

Statistics were obtained with Student's paired $t$ test.

\section{References}

Avanzi GC, Brizzi MF, Giannotti J, Ciarletta A, Yang YC, Pegoraro L, and Clark SC (1990). M-07E human leukemic factor dependent cell line provides a rapid and sensitive bioassay for the human cytokines GM-CSF and IL-3. J Cell Physiol 145:458-464.

Bernstein ID, Andrews RG, and Zsebo KM (1991). Recombinant human stem cell factor enhances the formation of colonies by CD34+ and CD34 + lin-cells, and the generation of colony-forming cell progeny from CD34+ lin-cells cultured with interleukin-3, granulocyte colony-stimulating factor, or granulocyte-macrophage colony-stimulating factor. Blood 77:2316-2321.

Biedler JL, Helson L, and Spengler BA (1973). Morphology and growth, tumorigenicity, and cytogenetics of human neu- roblastoma cells in continous culture. Cancer Res 33:26432652.

Biedler JL, Roffler-Tarlov S, Shachner M, and Freedman LS (1978). Multiple neurotransmitter synthesis by human neuroblastoma cell lines and clones. Cancer Res 38: 3751-3757.

Birg F, Courcoul M, Rosnet O, Bardin F, Pebusque MJ, Marchetto S, Tabilio A, Mannoni P, and Birnbaum D (1992). Expression of the FMS/kit-like gene flt3 in human acute leukemias of the myeloid and lymphoid lineages. Blood 80:2584-2593.

Bjornson CR, Rietze RL, Reynolds BA, Magli MC, and Vescovi AL (1999). Turning brain into blood: A hematopoietic fate adopted by adult neural stem cells in vivo. Science 283:534-537.

Broxmeyer HE, Lu L, Cooper S, Ruggeri L, Li ZH, and Lyman SD (1995). Flt-3 ligand stimulates/costimulates the growth of myeloid stem/progenitor cells. Exp Hematol 23:1121-1129.

Cohen PS, Chan JP, Lipkunskaya J, Seeger RC, and the Children's Cancer Group (1994). Expression of stem cell factor and c-kit in human neuroblastoma. Blood 84:34653472.

Drexler HG, Meyer C, and Quentmeier H (1999). Effects of flt3 ligand on proliferation and survival of myeloid leukemia cells. Leuk Lymphoma 33:83-91.

Drouet M, Mathieu J, Grenier N, Multon E, Sotto JJ, and Herodin $F$ (1999). The reduction of in vitro radiation-induced FAS-related apoptosis in CD34+ progenitor cells by SCF, FLT-3 ligand, TPO, and IL-3 in combination resulted in CD34+ cell proliferation and differentiation. Stem Cells 17: 273-285. 
Eglitis MA and Mezey E (1997). Hematopoietic cells differentiate into both microglia and macroglia in the brains of adult mice. Proc Natl Acad Sci USA 94: 4080-4085.

Hannum C, Culpepper J, Campbell D, McClanahan T, Zurawski S, Bazan JF, Kastelein R, Hudak S, Wagner J, Mattson J, Luh J, Duda G, Martina N, Peterson D, Mnon S, Shanafelt A, Muench M, Kelner G, Namikawa R, Rennick D, Roncarolo MG, Zlotnik A, Rosnet O, Dubreuil P, Birnbaum D, and Lee F (1994). Ligand for flt3/flk2 receptor tyrosine kinase regulates growth of hemopoietic stem cells and is encoded by variant RNAs. Nature 368:643-648.

Hunte BE, Hudak S, Campbell D, Xu Y, and Rennick D (1996). $\mathrm{flk} 2 / \mathrm{flt} 3$ ligand is a potent cofactor for the growth of primitive B cell progenitors. J Immunol 156:489-496.

Jacobsen SE, Okkenhaug C, Myklebust J, Veiby OP, and Lyman SD (1995). The flt-3 ligand potently and directly stimulates the growth and expansion of primitive murine bone marrow progenitor cells in vitro: Synergistic interactions with interleukin (IL)-11, IL-12, and other hematopoietic growth factors. J Exp Med 181:1357-1363.

Lisovsky M, Braun SE, Ge Y, Takahira H, Lu L, Savchenko VG, Lyman SD, and Broxmeyer HE (1996). Flt3-ligand production by human bone marrow stromal cells. Leukemia 10:1012-1018.

Lyman SD (1998). Biologic effects and potential applications of Flt3 ligand. Curr Opin Hematol 5:192-196.

Lyman SD and Jacobsen SEW (1998). C-kit ligand and flt-3 ligand: Stem-progenitor cell factors with overlapping yet distinct activities. Blood 91:1101-1134.

Lyman SD, James L, Johnson L, Brasel K, de Vries P, Escobar SS, Downey $H$, Splett RR, Beckmann MP, and McKenna HJ (1994). Cloning of the human homologue of the murine flt3 ligand: A growth factor for early hematopoietic progenitor cells. Blood 83:2795-2801.

Lyman SD, James L, Sanden Bos T, de Vries P, Brasel K, Gliniak B, Hollingsworth LT, Picha KS, McKenna HJ, Splett RR, Fletcher F, Maraskowsky E, Farrah T, Foxworthe D, Williams D, and Beckmann P (1993). Molecular cloning of a ligand for the flt-3/flk-2 tyrosine kinase receptor: A proliferative factor for primitive hematopoietic cells. Cell 75:11571167.

McConnell HM, Owic JC, and Parce JW (1992). The microphysiometer: Biological appliction of silicon technology. Science 257:1906-1912.

Molineux G, McCrea C, Yan XQ, Kerzic P, and McNiece I (1997). Flt-3 ligand synergizes with granulocyte colonystimulating factor to increase neutrophil numbers and to mobilize peripheral blood stem cells with long-term repopulating potential. Blood 89:3998-4004.

Ohm JE, Shurin MR, Esche C, Lotze MT, Carbone DP, and Gabrilovich DI (1999). Effect of vascular endothelial growth factor and flt3 ligand on dendritic cell generation in vivo. J Immunol 163:3260-3268.

Pagani A, Macri L, Rosolen A, Toffolatti L, Stella A, and Bussolati G (1998). Neuroendocrine differentiation in Ewing's sarcomas and primitive neuroectodermal tumors revealed by reverse transcriptase-polymerase chain reaction of chromogranin mRNA. Diagn Mol Pathol 7:36-43.

Ponte P, Ng SY, Engel J, Gunning P, and Kedes L (1984). Evolutionary conservation in the untranslated regions of actin
mRNAs: DNA sequence of a human beta-actin c-DNA. Nucleic Acids Res 12:1687-1696.

Papayannopoulou T, Nakamoto B, Andrews RG, Lyman SD, and Lee MY (1997). In vivo effects of Flt3/Flk2 ligand on mobilisation of hematopoietic progenitors in primates and potent synergistic enhancement with granulocyte colonystimulating factor. Blood 90:620-629.

Quesenberry PJ, Hulspas R, Joly M, Benoit B, Engstrom C, Rielly J, Savarese T, Pang L, Recht L, Ross A, Stein G, and Stewart M (1999). Correlates between hematopoiesis and neuropoiesis: Neural stem cells. J Neurotrauma 16:661-666.

Rasko jej, Metcalf D, Rossner MT, Begley CG, and Nicola NA (1995). The flt3/flk2 ligand: Receptor distribution and action on murine haematopoietic cell survival and proliferation. Leukemia 9:2058-2066.

Ray RJ, Paige CJ, Furlonger C, Lyman SD, and Rottapel R (1996). Flt3 ligand supports the differentiation of early B cell progenitors in the presence of interleukin-11 and interleukin-7. Eur J Immunol 26:1504-1510.

Reyes M and Verfaillie CM (1999). Turning marrow into brain: Generation of glial and neuronal cells from adult bone marrow mesenchymal stem cells. Blood 94(Suppl 1):377a.

Ricotti E, Bertorello N, Vai S, Pagani A, Cordero di Montezemolo L, Madon E, and Basso G (1999). Stem cell factor is not essential for cell survival and proliferation of soft tissue sarcoma of neuroectodermal origin. Haematologica 84:879886.

Ricotti E, Fagioli F, Garelli E, Linari C, Crescenzio N, Horenstein AL, Pistamiglio P, Vai S, Berger M, Cordero di Montezemolo L, Madon E, and Basso G (1998). C-kit is expressed in soft tissue sarcoma of neuroectodermic origin and its ligand prevents apoptosis of neoplastic cells. Blood 91: 2397-2405.

Rocchi P, Ferreri AM, Simone G, and Prodi G (1987). Epirubicin-induced differentiation of human neuroblastoma cells in vitro. Anticancer Res 7:247-250.

Rosnet O and Birnbaum D (1993). Hematopoietic receptors of class III receptor-type tyrosine kinases. Crit Rev Oncog 4:595-613.

Rosnet O, Marchetto S, deLapeyriere O, and Birnbaum D (1991). Murine flt3, a gene encoding encoding a novel tyrosine kinase receptor of the PDGFR/CSF1R family. Oncogene 6:1641-1650.

Rosnet O, Schiff C, Pébusque MJ, Marchetto S, Tonnelle C, ToironY, Birg F, and Birnbaum D (1993). Human FLT3/FLK2 gene: c-DNA cloning and expression in hematopoietic cells. Blood 82:1110-1119.

Salon JA and Owicki JC (1994). Real time measurements of receptor activity: Application of microphysiometric tecniques to receptor biology. In: Sealfon SC, editor. Methods in neuroscience: Receptor molecular biology, vol 25. San Diego: Academic Press, 201-224.

Schlesinger HR, Gerson JM, Moorhead PS, Maguire H, and Hummeler K (1976). Establishment and characterisation of human neuroblastoma cell lines. Cancer Res 36:3094-3100.

Shibuya M, Yamaguchi S, Yamane A, Ikeda T, Tojo A, Matsushime H, and Sato M (1990). Nucleotide sequence and expression of a novel human receptor-type tyrosine kinase gene (flt) closely related to the fms family. Oncogene 5:519524. 
Sieber-Blum M (1998).Growth factor synergism and antagonism in early neural crest development. Biochem Cell Biol 76:1039-1050.

Thiele CJ, McKeon C, Triche TJ, Ross RA, Reynolds CP, and Israel MA (1987). Differential protooncogene expression characterizes histopatologically indistinguishable tumors of the peripheral nervous system. J Clin Invest 80:804-811.

Timeus F, Crescenzio N, Valle P, Pistamiglio P, Piglione M, Garelli E, Ricotti E, Rocchi P, Strippoli P, Cordero di Montezemolo L, Madon E, Ramenghi U, and Basso G (1997). Stem cell factor suppresses apoptosis in neuroblastoma cell lines. Exp Hematol 25:1253-1260.

Vanu N, Deng D, Lyman SD, and Abraham H (1999). Modulation of haematopoietic progenitor development by flt-3 ligand. Cytokine 11:679-688.

Yarden Y, Knaung WJ, Yang-Feng T, Coussens L, Munemitsu S, Dull TJ, Chen E, Schlessinger J, Francke U, and Ullrich A (1987). Human protooncogene c-kit: A new cell surface receptor tyrosine kinase for an unidentified ligand. EMBO J 6:3341-3351.
Zeigler FC, Benett BD, Jordan CT, Spencer SD, Baumhueter S, Carroll KJ, Hooley Jeffrey, Bauer K, and Matthews W (1994). Cellular and molecular characterisation of the role of the flk-2/flt-3 receptor tyrosine kinase in hematopoietic stem cells. Blood 84:2422-2430.

Zsebo KM, Williams DA, Geisslereissler EN, Broudy VC, Martin FH, Atkins HL, Hsu RY, Birkett NC, Okino KH, Murdock DC, Yacobson FW, Langley KE, Smith AK, Eishi T, Cattanach BM, Galli SJ, and Suggs SV (1990). Stem cell factor (SCF) is encoded at the SI locus of the mouse and is the ligand for the c-kit tyrosine kinase receptor. Cell 63:213224 